\title{
MEASUREMENT OF METHANE AND OTHER ATMOSPHERIC POLLUTANTS EMITTED BY FLOODED PADDY FIELDS
}

\section{Svetla Dimitrova}

University of Agribusiness and Rural Development, Plovdiv, Bulgaria

The increase of methane concentration has been established during the last decades. This gas has a relative potential for thermal absorption, 30 times higher than $\mathrm{CO}_{2}$, which means that it is more active in the interaction with the ozone and its blocking. About $70 \%$ of the global total emission of methane in the atmosphere is of biogenic origin. Flooded paddy fields are one of the main sources of atmosphere pollutions with methane. Irrigation of rice fields by overflowing reduces the feeding of the ground with oxygen from the air. This in turn affects the fermentation of organic substances in the ground. Methane is the final product in this process. The measurement was performed in the phase of rice earing by an authorized laboratory associated to the Executive Environment Agency at the Ministry of Waters and Environment by means of methods specified by the Ministry. The concentrations of damaging substances were automatically measured at every 60 min for $\mathrm{SO}_{2}, \mathrm{NO}_{2}, \mathrm{NO}$, and at every 30 min for $\mathrm{H}_{2} \mathrm{~S}, \mathrm{CH}_{4}, \mathrm{NMHC}, \mathrm{CO}$, and $\mathrm{NH}_{3}$. The obtained results prove that the concentrations of NO, $\mathrm{H}_{2} \mathrm{~S}, \mathrm{CH}_{4}$ and $\mathrm{NMHC}$ exceed all limits. The quantity of gases is influenced by the variety peculiarities of the culture (the roots mass, the total bio-mass and the running metabolic processes).

Keywords: air pollution, flooded paddy fields, variety peculiarities

Flooded rice fields are probably one of the largest agricultural sources of methane. Flooding a rice field cuts off the oxygen supplied by the atmosphere to the soil; this results in fermentation of the soil organic matther. Methane is a major end product of this process. Flooded rice fields release methane to the atmosphere by diffusion, ebullition, or through the rice plants, which mediate the transport of methane from the reduced soil to the atmosphere (Fig.1). Much of

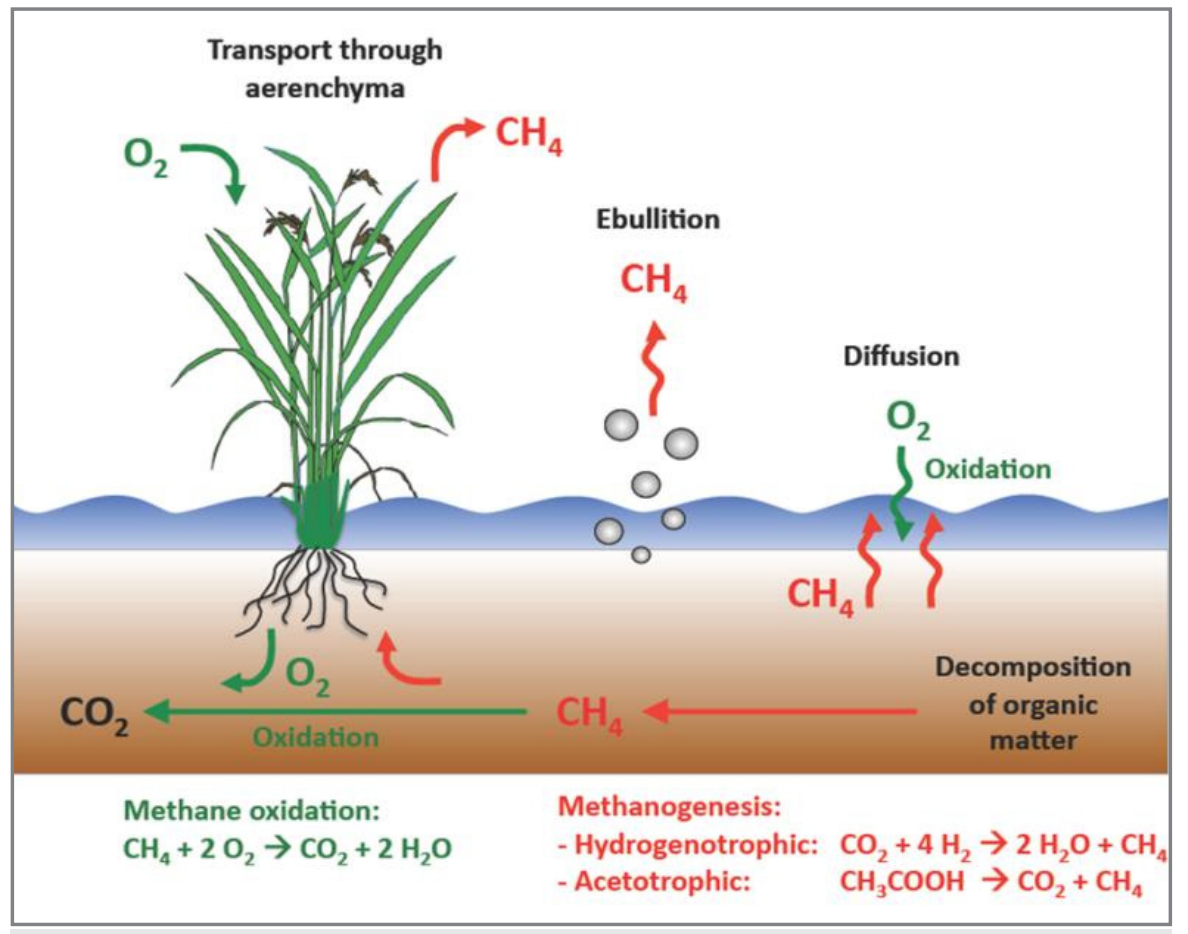

Fig. 1 Scheme of methane $\left(\mathrm{CH}_{4}\right)$ production, oxidation, and emission in flooded rice fields the methane formed in the anaerobic soil may remain entrapped in the soil and is oxidized to $\mathrm{CO}_{2}$.

Rice plants play an important role in the flux of methane. Up to $90 \%$ of the methane released from ricefields into the atmosphere is emitted through rice plants. Well-developed intracellular air spaces (aerenchyma) in leaf blades, leaf sheats, culm and roots provide an efficient gas exchange medium between the atmosphere and the anaerobic soil (Fig 1).

Atmospheric oxygen needed for respiration is supplied through aerenchyma to the roots. Gases formed in the soil, such as methane, diffuse from the reduced soil through the aerenchyma to the atmosphere. Production and transport of methane to the atmosphere appear to depend on the rice plants properties. Rice plants do not only mediate methane flux; root exudates and degrading roots are important sources of methane, especially at later growth stages.

\section{Aims and background}

Our purpose with the present research is to determine the exact concentrations of methane and other atmospheric pollutants and whether there exists any dependence between the variety peculiarities and concentrations of the emitted gases. 


\section{Material and methods}

To determine the quality of the atmosphere air over the flooded paddy fields a measurement of the atmosphere pollutants was conducted. The measurement was performed in the phase of rice earing by an authorized laboratory associated to the Executive Environment Agency at the Ministry of Waters and Environment by means of methods specified by the Ministry. The concentrations of damaging substances were automatically measured at every 60 min for $\mathrm{SO}_{2}, \mathrm{NO}_{2}, \mathrm{NO}$, and at every 30 min for $\mathrm{H}_{2} \mathrm{~S}, \mathrm{CH}_{4}, \mathrm{NMHC}, \mathrm{CO}$, and $\mathrm{NH}_{3}$. The highest allowed concentrations ( $\mathrm{HAC}$ ) are cited in the Decrees № 8 and 9 of May 3, 1999 about $\mathrm{SO}_{2}, \mathrm{NO}_{2}, \mathrm{NO}$ and $\mathrm{O}_{3}$, in the Decree №14 of September 23, 1997, about $\mathrm{H}_{2} \mathrm{~S}, \mathrm{CH}_{4}, \mathrm{NMHC}, \mathrm{CO}$, and $\mathrm{NH}_{3}$ by the Ministry of Waters and Environment. We used two varieties of rice in our research, which differ in a number of indicators. After the vegetation of the culture was over, we measured the dry substance of the plants (roots, steams, leaves and ear) per $\mathrm{m}^{2}$ to determine some relation between peculiarities of the plant and emitted gases.

\section{Results and discussion}

The concentrations obtained from the conducted research are shown in Tables 1-4. After analysing the obtained results, we classified the atmosphere pollutants into three groups for both varieties:

Group I - $\mathrm{SO}_{2}, \mathrm{NO}_{2}, \mathrm{O}_{3}, \mathrm{CO}$ and $\mathrm{NH}_{3}$ - with measured concentrations being lower than allowable limits;
Group II - $\mathrm{H}_{2} \mathrm{~S}$ - with concentrations lower than the allowable limits - but not for each period of $30 \mathrm{~min}$;

Group III - NO, $\mathrm{CH}_{4}$ and $\mathrm{NMHC}$ - with concentrations over the allowable limits for all sub-periods of time.

The concentrations of the measured gases vary within the following limits:

ㄷ $\mathrm{SO}_{2}$ - from 2 to $22 \mathrm{mg} / \mathrm{m}^{3}$ with the varieties of Baldo, and from 2 to $18 \mathrm{mg} / \mathrm{m}^{3}$ with Kostievo;

ㅁ $\mathrm{NO}_{2}$ - from 9 to $31 \mathrm{mg} / \mathrm{m}^{3}$ with the varieties of Baldo, and from 9 to $26 \mathrm{mg} / \mathrm{m}^{3}$ with Kostievo;

ㅁ $0_{3}-$ from 79 to $114 \mathrm{mg} / \mathrm{m}^{3}$ with the varieties of Baldo, and from 80 to $113 \mathrm{mg} / \mathrm{m}^{3}$ with Kostievo;

ㄷ $\mathrm{NH}_{3}$ - from 0.001 to $0.017 \mathrm{mg} / \mathrm{m}^{3}$ with the varieties of Baldo, and from 0.001 to $0.011 \mathrm{mg} / \mathrm{m}^{3}$ with Kostievo;

$\square \mathrm{CO}-$ from 0.3 to $1.9 \mathrm{mg} / \mathrm{m}^{3}$ with the varieties of Baldo, and from 0.1 to $1.8 \mathrm{mg} / \mathrm{m}^{3}$ with Kostievo;

$\square \mathrm{H}_{2} \mathrm{~S}-$ from 0.000 to $0.016 \mathrm{mg} / \mathrm{m}^{3}$ with the varieties of Baldo, and from 0.000 to $0.014 \mathrm{mg} / \mathrm{m}^{3}$ with Kostievo;

ㅁ $\mathrm{N} 0$ - from 1 to $7 \mathrm{mg} / \mathrm{m}^{3}$ with the varieties of Baldo, and from 1 to $7 \mathrm{mg} /$ $\mathrm{m}^{3}$ with Kostievo;

$\square$ NMHC - from 1.0 to $4.3 \mathrm{mg} / \mathrm{m}^{3}$ with the varieties of Baldo, and from 0.7 to $4.0 \mathrm{mg} / \mathrm{m}^{3}$ with Kostievo;

$\square \mathrm{CH}_{4}-$ from 0.9 to $3.3 \mathrm{mg} / \mathrm{m}^{3}$ with the varieties of Baldo, and from 0.7 to $2.9 \mathrm{mg} / \mathrm{m}^{3}$ with Kostievo.

Table 1 Quality of the atmosphere air - date July 31 (variety Baldo)

\begin{tabular}{|c|c|c|c|c|c|c|c|c|c|}
\hline \multirow{2}{*}{$\begin{array}{l}\text { Time } \\
\text { HAC* }\end{array}$} & \multicolumn{9}{|c|}{ Atmospheric pollutants (mg/m³) } \\
\hline & $\begin{array}{l}\mathrm{SO}_{2} \\
500\end{array}$ & $\begin{array}{l}\mathrm{NO}_{2} \\
300\end{array}$ & $\begin{array}{l}\text { NO } \\
0.0\end{array}$ & $\begin{array}{c}0_{3} \\
180\end{array}$ & $\begin{array}{c}\mathrm{H}_{2} \mathrm{~S} \\
0.008\end{array}$ & $\begin{array}{l}\mathrm{CH}_{4} \\
0.00\end{array}$ & $\begin{array}{c}\text { NMHC } \\
0.00\end{array}$ & $\begin{array}{c}C 0 \\
60.0\end{array}$ & $\begin{array}{l}\mathrm{NH}_{3} \\
0.20\end{array}$ \\
\hline 12.00 & 5 & 14 & 3 & 88 & 0.000 & 2.6 & 3.9 & 0.4 & 0.012 \\
\hline 12.30 & - & - & - & - & 0.000 & 2.8 & 4.3 & 0.6 & 0.011 \\
\hline 13.00 & 2 & 23 & 4 & 80 & 0.000 & 2.2 & 3.6 & 0.4 & 0.017 \\
\hline 13.30 & - & - & - & - & 0.005 & 1.0 & 1.2 & 0.6 & 0.010 \\
\hline 14.00 & 8 & 31 & 7 & 104 & 0.0010 & 0.9 & 1.1 & 0.9 & 0.004 \\
\hline 14.30 & - & - & - & - & 0.012 & 1.2 & 1.7 & 1.0 & 0.003 \\
\hline 15.00 & 12 & 19 & 3 & 111 & 0.012 & 1.3 & 2.2 & 0.8 & 0.002 \\
\hline 15.30 & - & - & - & - & 0.016 & 1.7 & 2.6 & 0.9 & 0.004 \\
\hline 16.30 & - & - & - & - & 0.010 & 1.6 & 2.2 & 1.1 & 0.002 \\
\hline 17.00 & 9 & 18 & 4 & 80 & 0.009 & 2.2 & 2.9 & 0.8 & 0.007 \\
\hline 17.30 & - & - & - & - & 0.012 & 1.8 & 2.4 & 0.5 & 0.007 \\
\hline 18.00 & 8 & 18 & 4 & 79 & 0.014 & 1.3 & 2.2 & 0.4 & 0.012 \\
\hline 18.30 & - & - & - & - & 0.015 & 1.4 & 2.5 & 0.4 & 0.010 \\
\hline 19.00 & 8 & 22 & 6 & 81 & 0.013 & 1.3 & 2.5 & 0.4 & 0.008 \\
\hline
\end{tabular}

${ }^{*} \mathrm{HAC}$ - highest allowed concentration 
Table 2 Quality of the atmosphere air - date August 1 (variety Baldo)

\begin{tabular}{|c|c|c|c|c|c|c|c|c|c|}
\hline \multirow{2}{*}{$\begin{array}{l}\text { Time } \\
\text { HAC* }\end{array}$} & \multicolumn{9}{|c|}{ Atmospheric pollutants $\left(\mathrm{mg} / \mathrm{m}^{3}\right)$} \\
\hline & $\begin{array}{l}\mathrm{SO}_{2} \\
500\end{array}$ & $\begin{array}{l}\mathrm{NO}_{2} \\
300\end{array}$ & $\begin{array}{l}\text { NO } \\
\mathbf{0 . 0}\end{array}$ & $\begin{array}{c}0_{3} \\
180\end{array}$ & $\begin{array}{c}\mathrm{H}_{2} \mathrm{~S} \\
0.008\end{array}$ & $\begin{array}{c}\mathrm{CH}_{4} \\
0.00\end{array}$ & $\begin{array}{c}\text { NMHC } \\
0.00\end{array}$ & $\begin{array}{c}C 0 \\
60.0\end{array}$ & $\begin{array}{l}\mathrm{NH}_{3} \\
0.20\end{array}$ \\
\hline 08.30 & - & - & - & - & 0.000 & 2.3 & 2.9 & 0.7 & 0.008 \\
\hline 09.00 & 11 & 16 & 4 & 94 & 0.001 & 2.5 & 3.2 & 0.7 & 0.010 \\
\hline 09.30 & - & - & - & - & 0.002 & 2.8 & 3.6 & 0.5 & 0.009 \\
\hline 10.00 & 12 & 15 & 4 & 90 & 0.002 & 3.3 & 3.9 & 0.5 & 0.010 \\
\hline 10.30 & - & - & - & - & 0.002 & 2.0 & 2.3 & 0.4 & 0.004 \\
\hline 11.00 & 9 & 19 & 4 & 99 & 0.002 & 1.6 & 1.9 & 0.4 & 0.001 \\
\hline 11.30 & - & - & - & - & 0.005 & 1.0 & 1.4 & 0.3 & 0.003 \\
\hline 12.00 & 7 & 21 & 5 & 102 & 0.008 & 0.9 & 1.1 & 0.4 & 0.005 \\
\hline 12.30 & - & - & - & - & 0.008 & 0.9 & 1.0 & 0.5 & 0.007 \\
\hline 13.00 & 10 & 17 & 5 & 102 & 0.006 & 0.9 & 1.0 & 0.6 & 0.010 \\
\hline 13.30 & - & - & - & - & 0.006 & 1.0 & 1.4 & 0.7 & 0.009 \\
\hline 14.00 & 11 & 9 & 1 & 97 & 0.009 & 1.6 & 2.1 & 0.5 & 0.012 \\
\hline 14.30 & - & - & - & - & 0.009 & 2.0 & 2.6 & 0.5 & 0.014 \\
\hline 15.00 & 13 & 12 & 2 & 97 & 0.010 & 2.2 & 2.9 & 0.4 & 0.010 \\
\hline 15.30 & - & - & - & - & 0.011 & 2.5 & 3.2 & 0.3 & 0.008 \\
\hline
\end{tabular}

${ }^{*} \mathrm{HAC}$ - highest allowed concentration

Table 3 Quality of the atmosphere air - date July 31 (variety Kostievo)

\begin{tabular}{|c|c|c|c|c|c|c|c|c|c|}
\hline \multirow{2}{*}{$\begin{array}{l}\text { Time } \\
\text { HAC* }\end{array}$} & \multicolumn{9}{|c|}{ Atmospheric pollutants (mg/m³) } \\
\hline & $\begin{array}{l}\mathrm{SO}_{2} \\
500\end{array}$ & $\begin{array}{l}\mathrm{NO}_{2} \\
300\end{array}$ & $\begin{array}{l}\text { No } \\
0.0\end{array}$ & $\begin{array}{c}0_{3} \\
180\end{array}$ & $\begin{array}{c}\mathrm{H}_{2} \mathrm{~S} \\
0.008\end{array}$ & $\begin{array}{l}\mathrm{CH}_{4} \\
0.00\end{array}$ & $\begin{array}{c}\text { NMHC } \\
0.00\end{array}$ & $\begin{array}{c}C 0 \\
60.0\end{array}$ & $\begin{array}{l}\mathrm{NH}_{3} \\
0.20\end{array}$ \\
\hline 12.00 & 3 & 16 & 3 & 91 & 0.000 & 2.2 & 3.7 & 0.6 & 0.009 \\
\hline 12.30 & - & - & - & - & 0.000 & 2.2 & 4.0 & 0.5 & 0.010 \\
\hline 13.00 & 2 & 26 & 4 & 80 & 0.001 & 2.0 & 3.7 & 0.4 & 0.011 \\
\hline 13.30 & - & - & - & - & 0.004 & 0.7 & 1.2 & 0.5 & 0.009 \\
\hline 14.00 & 8 & 26 & 7 & 103 & 0.006 & 0.8 & 1.0 & 0.6 & 0.003 \\
\hline 14.30 & - & - & - & - & 0.009 & 1.2 & 1.4 & 0.8 & 0.003 \\
\hline 15.00 & 12 & 18 & 1 & 113 & 0.008 & 1.2 & 1.9 & 0.4 & 0.001 \\
\hline 15.30 & - & - & - & - & 0.014 & 1.5 & 2.4 & 0.9 & 0.001 \\
\hline 16.00 & 18 & 20 & 3 & 113 & 0.014 & 1.3 & 1.8 & 1.8 & 0.001 \\
\hline 16.30 & - & - & - & - & 0.009 & 1.5 & 2.0 & 1.0 & 0.004 \\
\hline 17.00 & 7 & 15 & 4 & 84 & 0.009 & 1.9 & 2.5 & 0.9 & 0.004 \\
\hline 17.30 & - & - & - & - & 0.011 & 1.6 & 2.0 & 0.5 & 0.010 \\
\hline 18.00 & 8 & 17 & 4 & 84 & 0.014 & 1.3 & 2.0 & 0.4 & 0.010 \\
\hline 18.30 & - & - & - & - & 0.010 & 1.2 & 2.2 & 0.4 & 0.008 \\
\hline 19.00 & 6 & 23 & 5 & 87 & 0.008 & 1.2 & 2.3 & 0.4 & 0.007 \\
\hline
\end{tabular}

* $\mathrm{HAC}$ - highest allowed concentration 
Table 4 Quality of the atmosphere air - date August 1 (variety Kostievo)

\begin{tabular}{|c|c|c|c|c|c|c|c|c|c|}
\hline \multirow{2}{*}{$\begin{array}{l}\text { Time } \\
\text { HAC* }\end{array}$} & \multicolumn{9}{|c|}{ Atmospheric pollutants (mg/m³) } \\
\hline & $\begin{array}{l}\mathrm{SO}_{2} \\
500\end{array}$ & $\begin{array}{l}\mathrm{NO}_{2} \\
300\end{array}$ & $\begin{array}{l}\text { NO } \\
0.0\end{array}$ & $\begin{array}{c}0_{3} \\
180\end{array}$ & $\begin{array}{c}\mathrm{H}_{2} \mathrm{~S} \\
0.008\end{array}$ & $\begin{array}{c}\mathrm{CH}_{4} \\
0.00\end{array}$ & $\begin{array}{c}\text { NMHC } \\
0.00\end{array}$ & $\begin{array}{c}C 0 \\
60.0\end{array}$ & $\begin{array}{l}\mathrm{NH}_{3} \\
0.20\end{array}$ \\
\hline 09.00 & 10 & 17 & 3 & 100 & 0.000 & 2.0 & 3.1 & 0.6 & 0.010 \\
\hline 09.30 & - & - & - & - & 0.001 & 2.4 & 3.4 & 0.5 & 0.009 \\
\hline 10.30 & - & - & - & - & 0.001 & 1.9 & 2.0 & 0.5 & 0.003 \\
\hline 11.00 & 8 & 19 & 4 & 98 & 0.000 & 1.3 & 1.6 & 0.3 & 0.002 \\
\hline 11.30 & - & - & - & - & 0.002 & 1.2 & 1.3 & 0.1 & 0.001 \\
\hline 12.00 & 7 & 19 & 6 & 103 & 0.005 & 0.7 & 1.1 & 0.3 & 0.004 \\
\hline 12.30 & - & - & - & - & 0.007 & 0.7 & 0.7 & 0.4 & 0.005 \\
\hline 13.30 & - & - & - & - & 0.003 & 0.8 & 1.0 & 0.7 & 0.008 \\
\hline 14.00 & 11 & 9 & 1 & 95 & 0.005 & 1.3 & 1.9 & 0.7 & 0.010 \\
\hline 14.30 & - & - & - & - & 0.007 & 1.9 & 2.2 & 0.2 & 0.011 \\
\hline 15.00 & 11 & 9 & 1 & 97 & 0.007 & 2.1 & 2.9 & 0.3 & 0.010 \\
\hline 15.30 & - & - & - & - & 0.009 & 2.4 & 3.0 & 0.4 & 0.006 \\
\hline
\end{tabular}

${ }^{*} \mathrm{HAC}$ - highest allowed concentration

Table 5 Dry stuff of the plants (roots, stems, leaves and ear) in $\mathrm{kg} / \mathrm{m}^{2}$

\begin{tabular}{|l|c|}
\hline Variety & Dry stuff of the plants $\left(\mathrm{kg} / \mathrm{m}^{2}\right)$ \\
\hline Baldo & 1.917 \\
\hline Kostievo & 1.691 \\
\hline
\end{tabular}

After analysing the data we came to the conclusion that the maximum values of the measured concentrations go higher with the Baldo variety (except for N0). Some dependence between the dry matter of the plants (roots, stems, leaves and ear in $\mathrm{kg} / \mathrm{m}^{2}$ ) in $\mathrm{m}^{2}$ and the emitted gases is being determined -1.917 for the variety Baldo and 1.691 for the variety Kostievo. They are higher with the better thriving Baldo variety.

What makes an impression is the fact that with $\mathrm{SO}_{2}, \mathrm{H}_{2} \mathrm{~S}, \mathrm{CH}_{4}, \mathrm{NMHC}$ and $\mathrm{NH}_{3}$ for each time interval (namely 30 and $60 \mathrm{~min}$ ) the concentrations are higher with the Baldo variety while $\mathrm{NO}_{2}, \mathrm{CO}$ and $\mathrm{NO}$ show maximum value with either sorts during the separate sub-periods of time (i.e. that is the case when the variety does not influence the emitted concentration of these gases but it depends on other factors - might be meteorological). $\mathrm{H}_{2} \mathrm{~S}, \mathrm{NO}$, NMHC and $\mathrm{CH}_{4}$ are over highest allowed concentration in flooded rice fields.

\section{Conclusions}

The analyses that we made of the quality of the atmosphere air over flooded rice fields lead us to the conclusion that the latter are sources of a number of gas pollutants, which are harmful to humans and environment, as their quantity is influenced by the variety peculiarities of the culture (the roots mass, the total bio-mass and the running metabolic processes).

The future trends should encompass the decrease in the harmful gas emissions of these gases. But it requires comprehensive information on the processes and the geographical distribution of the factors that control the flow of gases from the rice fields.

\section{References}

ALBERTO, M.C.R. - WASSMANN, R. - BURESH, R.J. - QUILTY, J.R. - CORREA JR., T.Q. - SANDRO, J.M. - CENTENO, C.A.R. 2014. Measuring methane flux from irrigated rice fields by eddy covariance method using open-path gas analyser. In Field Crop Res., vol. 160, 2014, pp. 12-21. ALBERTO, M.C.R. - WASSMANN, R. - GUMMERT, M. - BURESH, R.J. - QUILTY, J.R. - CORREA JR., T.Q. - CENTENO, C.A.R. - OCA, G.M. 2015. Straw incorporated after mechanized harvesting of irrigated rice affects net emissions of $\mathrm{CH}_{4}$ and $\mathrm{CO}_{2}$ based on eddy covariance measurements. In Field Crop Res., vol. 184, 2015, pp. 162-175.

ARAI, H. - HOSEN, Y. - PHAM HONG, V.N. - THI, N.T. - HUU, C.N. - INUBUSHI, K. 2015. Greenhouse gas emissions from rice straw burning and straw-mushroom cultivation in a triple rice cropping system in the Mekong Delta. In Soil Sci. Plant Nutr., vol. 61, 2015, pp. 719-735.

BUTTERBACH-BAHL, K. - SANDER, B.0. - PELSTER, D. - DIAZ PINES, E. 2016. Quantifying greenhouse gas emissions from soils and manure management. In Rosenstock, T.S. et al. (Eds.): Methods for Measuring Greenhouse Gas Balances and Evaluating Mitigation Options in Smallholder Agriculture, 2016, pp. 71-96.

DOBERMANN, A. - FAIRHURST, T.H. 2002. Rice straw management. In Better Crops Int, vol. 16, 2002, no. 1, pp. 7-11.

EGGLESTON, H.S. - BUENDIA, L. - MIWA, K. - NGARA, T. - TANABE, K. (Eds.). 2006. IPCC Guidelines for National Greenhouse Gas Inventories. In Prepared by the National Greenhouse Gas Inventories Programme, IGES, Japan, 2006.

GADDE, B. - BONNET, S. - MENKE, C. - GARIVAIT, S. 2009. Air pollutant emissions from rice straw open field burning in India, Thailand and the Philippines. In Environ. Pollut., vol. 157, 2009, no. 5, pp. 1554-1558.

GUPTA, P. - SAHAI, S. - SINGH, N. - DIXIT, C. - SINGH, D. - SHARMA, C. - TIWARI, M. - GUPTA, R. - GARG, S. 2004. Residue burning in rice-wheat cropping system: causes and implications. In Curr. Sci., vol. 87, 2004, no. 12, pp. 1713-1717.

HAYASHI, K. - ONO, K. - KAJIURA, M. - SUDO, S. - YONEMURA, S. - FUSHIMI, A. - SAITOH, K. FUIITANI, Y. - TANABE, K. 2014. Trace gas and particle emissions from open burning of three cereal crop residues Increase in residue moistness enhances emissions of carbon monoxide, methane, and particulate organic carbon. In Atmos. Environ., vol. 92, 2014, pp. 36-44.

NEUE, H.U. - WASSMAN, R. - LANTIN, R.S. - ALBERTO, M.C. - ADUNA, B. 1994. Methame emission from ricefield. In IRRI Notes, vol. 19, 1994, no. 3.

\section{Contact address}

Assoc. Prof. Svetla Dimitrova

University of Agribusiness and Rural Development,

Plovdiv 4003, boul. Dunav 78, Bulgaria

e-mail: tenova@abv.bg 